\title{
AN ANALYSIS OF STUDENT'S PROBLEMS IN SPEAKING AT ELEVENTH GRADE OF SMA NEGERI 1 SUKODADI
}

\author{
Alfi Syahidah Turada \\ alfisyahidahturada@gmail.com \\ English Language Education Department, Faculty of Teacher Training and Education, Universitas Islam \\ Lamongan
}

\begin{abstract}
Student usually faced several problems when speaking, such as lack of vocabulary and grammar. This research is focus on speaking skill as important skill of four basic language learning. Using qualitative descriptive method, researcher analysis students' problems in speaking of eleventh grade students in SMA Negeri 1 Sukodadi, Lamongan. The students' usually faced problems when speaking, such as lack of vocabulary and grammar. This research is guided by research problems as follows: (1) what are student's problems in speaking English at eleventh grade in SMA Negeri 1 Sukodadi. (2) What are the causes of students' problems in speaking English at eleventh grade in SMA Negeri 1 Sukodadi. Researcher used qualitative methods. In answering research problems, researcher used observations and interviews. The researcher uses three main phases of data analysis namely data reduction, data display, and drawing conclusions. Based on the data analysis, the result of research found the students problems, included the cause of problems in English speaking. In speaking English every students has their typical problems, but in general those can be stated as follows: lack of vocabularies, grammar, pronoun, comprehension and fluency. The researcher also found that the causes of students' problems are, lack of confidence, fear of mistakes, shyness, anxiety and low of motivation.
\end{abstract}

Keywords: Student's problem, speaking

\section{INTRODUCTION}

English is a compulsary subject in

high school because English has become a communication tool for all people throughout the world. In education, English has important roles in which several skills students must master, such as writing, reading, listening and speaking. Speaking is one of the skills that important for students must master in learning. By learning speaking, students will be able to communicate with others using English.
Students can convey their ideas through speaking. Speaking can help students be more active during learning, so speaking is a language skill that is very important and can support students' abilities when studying.

In fact, not all students are capable of speaking skills, many problems are experienced by students when learning to speak. According to Brown (2001: 270), some features make speaking a difficult language skill. That's why most people 
learn English. Speaking is a type of communication, according to Richard and Renandya (2002: 210), speaking is one of the main elements of communication. This is an aspect that needs special attention and instruction. To provide effective instructions. This means that speaking is a type of communication that must be discussed. We can say that anyone who lacks oral communication skills will suffer in this era of competition and may have difficulty reaching a higher position. Teaching speaking, usually the teacher will ask students to read dialogue, read in front of the class, learn, and memorize certain expressions and practice. In fact, students get less opportunity to talk, more attention is given than speaking, speaking is not easy for all students'. According to Hinkel's (2005) claim, communication problems occur because learners find words they do not understand, from words they do not know how to use or find that they cannot express the intended meaning. Another problem that arises in students' speaking is a lack of self-confidence and anxiety. They may feel comfortable with certain feelings that affect their English such as insecurity, shame, anxiety, anxiety, and worry. If students' self-themes don't believe they can speak, that has become a big problem for them. Most of them cannot speak English well because of many problems and factors. Sometimes students may want to speak English with others but they don't know what they want to say. Some students may lose words that are stored in their minds and cannot be expressed while speaking.

In teaching and learning activities according to the text above can be concluded that students have problems when speaking, not only problems there are also factors that cause problems to occur and this is what happens to eleventh grade students in grade in SMA Negeri 1 Sukodadi. Therefore the importance of making teaching and learning more diverse so that students can be more interested in participating in English learning activities. And make the students able to participate in 
learning. So students feel they will be more active in participating in the learning process.

In this research, the researcher analyze the problem and causes in speaking English of eleventh grade at SMA Negeri 1 Sukodadi. Sma Negeri 1 Sukodadi is a school that also applies English as a compulsory subject. The researcher had already observed the students when they learn English, especially in speaking. They have good motivation and enthusiasm for learning English, but their speaking skill is low. Hopefully this researcher will useful for English teachers, students, the readers, and especially for the researcher.

\section{RESEARCH METHOD}

This research is uses qualitative research. According to Afifuddin (2009:57) "qualitative methods are a research method used to examine the condition of natural objects, (the opposite is an experiment) where researchers are key instruments, data collecting techniques are carried out by triangulation (combined), data analysis is inductive, and qualitative research results emphasize more meaning than generalization" Qualitative method was chosen because this study aims at providing an insight into the case of students' problems in speaking English.

In this study, the researcher conducts the research at SMA Negeri 1 Sukodadi. The subject is the students in eleventh grade of SMA NEGERI 1 Sukodadi in the academic year of 2019/2020. The class consist of 29 students, 14 male and 15 female as the subjects of this research.

In this research, the researcher uses observation and interview to get the data in the field. The observations is used to observe student's problems in speaking. The researcher told to speak in front of class, the researcher told to introduce themselves in English. Then the researchers 
recorded the student activities gathering the researchers also noted on the observation sheet.

Then, the researcher conducted interview to the participant. The main point in this research is to know the problems and causes of students' problems in speaking English, so the researcher collects the data through the interview. The researcher uses a semi-structured interview to collect the data from the participant. Semi-structure interview method requires a person known as the interviewer asking the question generally in a face-to-face, but the researcher can add another questions to the participants. In this interview, the researcher made an interview with the students and with the English teacher.

\section{RESULT AND DISCUSSION}

\section{Students Problems in Speaking}

Based in the observation and interview result, the researcher found problems of in speaking. From the interview with the students and teacher, the researcher know about the causes of students' problem in speaking. It from the component in English There are: lack of vocabulary, grammar, pronunciation, comprehension and fluency.

a.) Vocabulary

The researcher found several problems in students speaking. One of the problem of speaking in students was vocabulary. According to Yendra $(45: 2018)$ vocabulary is total number of words that makes up a language, When the students performed their speaking in front of the class, the students felt confused when saying words and difficult choose words to say. While the students speaking, the students introduced himself but he had difficult and did not know how to said the word in English, such as "cita-cita itu apa (in english)".

[S] “Ya, saya juga tidak banyak tahu vocabulary" (interview, 05/03/2020) 
[S] 'Yes, i don't know much

vocbulary" (interview, 05/03/2020)

b.) Grammar

The students do not understand what grammar is, students do not know how to arrange grammar correctly. All of the students were in low mastering in English grammar, on occasion, the students made mistake in some grammar, they just says what they know. The students have no time to think, and they just improvise. However, they usually make mistake in arranging word or sentence, such as "I'am hobby football". The word "i am" should be replaced with "my”. Based on the students' interview, the students do not know what grammar is, so they do not know how to use grammar in English. The other students added that he did not know using English grammar correctly. It relate to the interview statement of the students.

[S] "Ya, saya tidak mengerti apa itu grammar di bahasa inggris" (interview, 05/03/2020)
[S] 'Yes, i don't understand what is grammar" (interview, 05/03/2020)

c.) Pronunciation

The students do not understand how to pronounce words while speaking. Sometimes the students made mistake even they speak. It happens when they try to speak English. They are still false pronunciation. The students did not know how to pronunciation the words, maybe the students were knew to pronounce, but the students not believe themselves, they were fell afraid if they made a mistake in term of pronunciation the words. Most of students have lack of confidence to pronounce. When students pronouncing the words, their pronunciation sound are not good enough. The problems happened because they are influence by their mother tongue. For example: "Old" is pronounced "Ol", not "ōld"

\section{[D] "Iya, saya tidak mengerti} pengucapan yang benar" (interview, 12/03/2020) 
[D] 'Yes, $i$ don't understand the correct pronunciation" (interview, $12 / 03 / 2020)$

d.) Comprehension

The researcher found that the students has a low ability to understand when the teacher speaks English, so the problem of students is, did not comprehends it. The students explained that the students do not understand what teacher speak, especially in English.

[R] "Iya, saya kurang bisa paham pada saat guru menjelaskannya" (interview, 12/03/2020)

[R] "Yes, $i$ could undertstand it when the teacher explined" (interview, $12 / 03 / 2020)$

e.) Fluency

The researcher found that the students have lack of fluency. They students used mother tongue in every day. And they can speak fluently when they try to speak in English. The students explained, especially when speaking English the students does not speak fluency,

[D] "iya, saya tidak lancar saat berbicara apalagi dalam bahasa inggris" (interview, 12/03/2020).

[D] 'Yes, I'am not fluent when speaking in English" (interview, 12/03/2020).

\section{The Causes of Students Problem in}

\section{Speaking}

Based on the interview result, the researcher found several causes of students' problem in speaking. Based on the interview with the students and teacher, the researcher know about the causes of students' problem in speaking. There are: lack of confidence, fear of mistake, anxiety, shyness and lack of motivations.

\section{a.) Lack of Confidence}

The respondent said that lack of confidence is the causes of the students' problems in speaking. The important in speaking is confidence. When someone try to speak English, they must have big confidence, it can help them to speak 
confidence. At least, while the students stand up and trying to continue their speaking as good as they can. No matter what they speak. When they have big confidents it can help them. The cause of the problems students is lack of confidence. The students felt that their ability in speaking is not good, so they does not believe what they speak in English. The researcher found the students have lack of confidence. The students said when they speaking in English they were not confidence because they cannot speak fluently.

Data interview 1:

[S] “Ya, saya kurang percaya diri karena tidak lancar saat bicara “

(Interview,,05/03/2020)

[S] "Yes, I have lack of confidence because i'am not fluent when speaking. (Interview,,05/03/2020) b.) Fear of Mistake
The students afraid of making mistakes when they speak English, another students would be laughing to the students. The situations can gave the negative effect for the students who trying to show themselves in front of their friends. The students may never tried to speak in front of another people again. the researcher found that the students have fear of mistake, the students said that she was afraid to speak in English.

Data interview 3:

[R] "Iya, saya takut salah saat mengucapkan bahasa inggis" (interview, 12/03/2020).

$$
\text { [R] " Yes, I'am afraid of }
$$
mispronunciation English" (interview, 12/03/2020).

c.) Anxiety

The students felt anxiety because they cannot speak well in English, they were not accustomed to using English, and they felt anxiety if the researcher ask them 
to speak in English. The students felt anxiety, when they speak in front of class.

The students explained that she

felt nervous when the teacher tell to speak English in front of class

Data interview 4:

[D] "gugup jika di suruh berbicara maju di depan kelas" (interview, $12 / 03 / 2020)$

[D] "nervous when asked to speak forwaard in front of class" (interview, $12 / 03 / 2020)$

d.) Shyness

The students felt shy when they tried to speak English. All these feelings are hidden by students when they try to speak in English. Sometimes, the students fell they cannot use English well. It make the students shy to speak in English, the students fell unconfident to speak English and the student being lazy to learning English. The students explained that she felt shy when speaking English, because the students cannot speak English.
[D] "Saya merasa malu karena tidak bisa bahasa inggris" (interview, $12 / 03 / 2020)$

[D] “ I feel ashamed because i can't speak English" (interview, 12/03/2020)

e.) Lack of Motivation

There were no motivation of the students to learn English seriously. Interesting in English is need to be increasing. The students have not motivation to study English. The students not like English so much and the students likes English, but the students cannot understand English. They low of motivation can came from the material, the teacher, and the environment.

The researcher found that the students need motivation to be more active and enthusiastic in learning English. The students said he need motivation in order to speak English.

Data interview 5: 
[A] "saya merasa perlu motivasi agar lebih bisa dalam bahasa inggris" (interview, 12/03/2020).

[A] " I feel need motivation to be more fluent in speaking English"

\section{CONCLUSION}

Based on the analysis of data, the problems of students of SMA 1 Sukodadi Lamongan in speaking English are as follows: a) most of students did not know the component of speaking, as the students problems faced the students is vocabulary, grammar, pronunciation, comprehension and fluency. Furthermore the problems students is from component in English. b) the cause of students problems in speaking are: lack of confidence. In learning speaking English, students did not confidence by them-self to speaking in English. Fear of mistake, lack of motivation, shyness, and anxiety.

\section{REFERENCES}

Affifuddin. (2009). Metodologi Penelitian Kualitatif. bandung: cv. pustaka setia.

Barnhart, C. A. (2008). The Facts On File Student's Dictionary of American English. . Facts on File, Inc.

Brown, D. H. (2000). Principles of language learning \& teaching. (4th ed.). New York: longman.

Brown, H. D. (2001). Brown, $H$. DougTeaching by Principle and InteractiveApproach to language pedagogy. New York: Longman Inc.

Brown, H. D. (2007). Principles of Language Learning and Teaching. USA: Longman.

Creswell, J. ( 2007). Educational Research. London: SAGE Publication.

David P. Harris. (1969). Testing English as A Second Language. New York: McGrawHill Book Company.

Harmer, J. (2002). The Practice of English Language Teaching. New England: longman.

Harmer, J. (2007). The Practice of English Language Teaching. Malaysia: Pearson Education Longman.

Hinkel, E. (2005). Analysis of second language text and what can be learned from them. In E. Hinkel (Ed.), Handbook of research in second language teaching and learning (pp. 615-628). New Jersey: Hinkel, E. (2005). Analysis of second language text and what can be learned from them. In E. Hinkel 
(Ed.), Handbook Lawrence Erlbaum Associate.

Jack.C, R. (2007). Developing Classroom Speaking Activities; From Theory to Practice. Http://www.professorjackrichard.c om/developingclassoomspeakingactivities.pdf, p.2.

Juhana. (2012). Psychological Factors That Hinder Students from Speaking in English Class. Tanggerang.

Luoma, S. (2004). Assessing speaking. Cambridge. Cambridge: Cambridge University Press.

Nunan, D. (2004). Task-Based Language Teaching. Cambridge: Cambridge University Press.

Richard, J. C. (2002). An Anthology of Current Practice. Cambridge: Cambridge University.
Sari, D. N. (2014). A Study of Students' Problems in Learning Speaking English at The Second Grade of SMPN 1 Telaga. Faculty of Tarbiyah and Teaching Science of Syekh Nurjati State Institute for Islamic Studies of Cirebon. Available on http://repository.syekhnurjati.ac.id/ 2954/1/DEVI\%20NOVITA\%20SW ARYmin.pdf.

Sugiyono. (2016). Metode Penelitian Kuantitatif, Kualitatif dan $R \& D$. Bandung: PT Alfabet. Danandjadja.

Swan, M. (2005). Practical English usage. International student edition. Oxford : Oxford University Press; 3 edition.

Thornbury, S. (2005). How to Teach Speaking. New York : Pearson Education Limited.

UR, P. (1991). A Course in Language Teaching (Practice and Theory). Cambridge: Cambridge Unive 